\title{
Результати лікування кератоконусу методом рогівкового крос-лінкінгу
}

\author{
T. A. TABALYUK \\ SHEI "Ternopil State Medical University by I. Ya. Horbachevsky"
}

THE RESULTS OF KERATOCONUS TREATMENT BY CORNEAL CROSS-LINKING METHOD

\begin{abstract}
Під нашим спостереженням протягом 6 місяців перебували 15 паціснтів (30 очей) із білатеральним кератоконусом, на одному оці кожного 3 яких із більш розвинутим захворюванням було проведено трансепітеліальний крос-лінкінг. Проводився моніторинг показників візометрії, пахіметрії та кератометрії. Було показано, що після крос-лінкінгу гострота зору без корекції та 3 контактною корекцією поступово підвищується, рогівка стас товстішою та плоскішою. Водночас на парному оці захворювання продовжувало прогресувати, про що свідчить зниження показників гостроти зору та товщини рогівки і підвищення ії заломної здатності за даними центральної кератометрії.

15 patients (30 eyes) with bilateral keratoconus were under our follow-up during 6 months. Transepithelial cross-linking was performed on one eye of each patient with more severe disease. Visometry, pachymetry and keratometry indices were monitored. It was shown gradual improving of visual acuity without correction and with contact lenses, corneal thickening and flattering after cross-linking. At the same time on other eye the disease continued to progress as visual acuity and pachymetry data decreased and corneal refractive power increased according to the central keratometry.
\end{abstract}

Постановка проблеми і аналіз останніх досліджень та публікацій. Крос-лінкінг, чи УФ-Х терапія, - це інноваційний парахірургічний метод лікування дистрофічних недуг рогівки. В основі його лежить хімічна реакція фотополімеризації колагенових волокон, що виникає у результаті комбінованої дії нешкідливої фоточутливої речовини рибофлавіну й ультрафіолетового випромінювання спектра А $з$ довжиною хвилі 365 нм. Молекула рибофлавіну розпадається з вивільненням короткоживучих вільних радикалів кисню, що сприяють утворенню додаткових поперечних містків між розрідженими внаслідок захворювання фібрилами колагену в стромі рогівки [1-4]. Основне призначення крослінкінгу - зміцнити рогівку, покращити ії біомеханічні властивості, що загальмує прогресування захворювання та дозволяє у ряді випадків уникнути складної операції їі трансплантації $[1,6]$. Крос-лінкінг відомий також як CCC-R, C3-R, UVA, CCL та UV-X терапія [3, 4].

Мета роботи: оцінити результати лікування кератоконусу методом рогівкового крослінкінгу.

Матеріали і методи. Під нашим спостереженням перебували 15 пацієнтів (30 очей) віком від 13 до 36 років 3 двобічним кератоконусом (середній

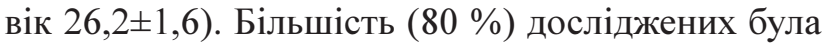
чоловічої статі. На одномі оці кожного пацієнта 3 більш розвинутим кератоконусом було проведено трансепітеліальний крос-лінкінг. Протягом 30 хв рогівку насичували розчином рибофлавіну, що інстилювався в око кожні 2 хв. Наступні 30 хв на рогівку діяло спеціально змодельоване і дозоване УФ-А

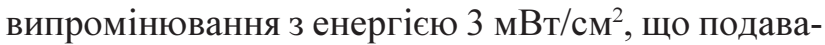
лось лінкером у шість 5-хвилинних фаз. Діаметр зони іррадіації становив 8-9 мм. Операція та післяопераційний період пройшли без ускладнень у всіх випадках.

Контрольними стали дані досліджень парного ока $з$ раннім кератоконусом. На 9 очах (60 \%) основної групи кератоконус був II стадії, а на 6 очах (40 \%) - III стадії за класифікацією Амслера-Крумеіх [5]. По 55 і 45 \% контрольної групи склали кератоконус I і II стадій відповідно.

Візометрію без корекції і з контактною корекцією, центральну кератометрію та УЗ-пахіметрію проводили до операції, а також через 1, 3 та 6 місяців після неї.

Результати досліджень та їх обговорення. Гострота зору без корекції у пацієнтів із кератоко- 
нусом була істотно знижена і коливалась від 0,02 до 0,5 (у середньому $0,18 \pm 0,04)$ на оці з більш розвинутим захворюванням та від 0,03 до 0,9 (у середньому $0,46 \pm 0,04)$ на парному оці. Після проведення крос-лінкінгу зір поступово підвищувався, тоді як відмічалась тенденція його погіршення на оці, де втручання не було. Так, через 1 місяць середні показники становили $0,22 \pm 0,04$ та $0,44 \pm 0,01$; через 3 місяці $-0,24 \pm 0,05$ та $0,44 \pm 0,01$, а через 6 місяців $-0,25 \pm 0,05$ і $0,43 \pm 0,01$ відповідно. I хоча різниця між початковими і піврічними показниками у кожній групі статистично незначима $(\mathrm{p}>0,05)$, та все ж закономірність щодо абсолютних показників звертає на себе увагу. Суб'єктивно більшість пацієнтів $(80 \%)$ відмічала поліпшення якості зору на оперованому оці вже з перших днів.

Контактна корекція підвищувала гостроту зору кератоконусних очей до нормальних показників (вище 0,6 в основній та вище 0,7 у контрольній групі), проте відмічалась аналогічна тенденція: на очах після крос-лінкінгу дані візометрії з корекцією поступово підвищувались (з $0,91 \pm 0,03$ у середньому на $0,94 \pm 0,03$ через 6 місяців), тоді як на парних спостерігалось їх пониження протягом півроку (з $0,95 \pm 0,01$ у середньому на $0,94 \pm 0,01)$. Показники гостроти зору наведено в таблиці 1.

Рогівка у кожного з пацієнтів на оці з розвинутим кератоконусом, де згодом було проведено УФ-Х терапію, була тоншою від парного з більш раннім кератоконусом і коливалась у найтоншій точці від 0,38 до 0,49 мм та від 0,39 до 0,53 мм відповідно. Вихідні середні показники пахіметрії становили $(0,41 \pm 0,01)$ та $(0,47 \pm 0,01)$ мм у I і II групі та були статистично достовірними $(\mathrm{p}<0,05)$. У ході піврічного спостереження відмічено тенденцію потовщення рогівки $(\mathrm{p}<0,05)$, на якій було проведено оперативне втручання, і витончення рогівки парного ока ( $>>0,05)$. Так, через 6 місяців показники в основній підгрупі коливались від 0,39 до 0,51 мм (у середньому $(0,44 \pm 0,01)$ мм), а в контрольній групі дані були у межах 0,40 до 0,53 мм та в середньому дорівнювали $(0,45 \pm 0,01)$ мм. Показник пахіметрії єдиний, що достовірно змінився в основній групі за 6 місяців спостереження. Крім того, через півроку різниця в пахіметрії найтоншої точки між основною $\mathrm{i}$ контрольною групами втратила свою достовірність порівняно з вихідною. Динаміка товщини рогівки наведена в таблиці 1.

Відповідно до даних центральної кератометрії спостерігався ефект сплощення більш ураженої рогівки після того, як вона була піддана крослінкінгу. Водночас рогівка з початковим кератоконусом, на якій УФ-Х терапію не проводили, ставала крутішою протягом 6 місяців. Так, в основній групі вихідні дані заломної сили крутішого меридіана (Kmax) коливались від 46,0 до 66,5 дптр; заломна сила слабшого меридіана (K min) - від 42,5 до 62,5 дптр, а різниця між ними (Kcyl) - від 1,5 до 9,0 дптр. А через півроку Kmax було у межах від 45,5 до 66,0 дптр; $\mathrm{K}$ min - від 42,0 до 62,0 дптр, Kcyl - від 1,0 до 8,5 дптр. У контрольній групі початкові дані Kmax були у межах від 42,5 до 57,0 дптр; $\mathrm{K}$ min - від 40,25 до 52,5 дптр, Kcyl - від 0,5 до 8,25 дптр. При повторному обстеженні за 6 місяців К max коливалось від 42,5 до 57,5 дптр; $\mathrm{K}$ min - від 40,25 до 52,5 дптр, Kcyl - від 0,75 до 8,5 дптр. Динаміку середніх значень Kmax, K min та Kcyl в основній та контрольній групах також наведено у таблиці 1.

Висновки. 1. Крос-лінкінг є безпечною, малоінвазивною та ефективною методикою лікування кератоконусу, що може застосовуватись навіть у дитячому віці.

2. Дистрофічно змінена рогівка поступово потовщується та стає плоскішою, покращується гострота зору як без корекції, так і з контактною корекцією після проведення крос-лінкінгу, що призупиняє прогресування кератоконусу.

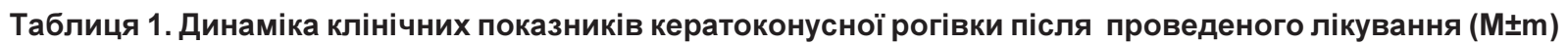

\begin{tabular}{|l|c|c|c|c|c|c|c|c|}
\hline \multirow{2}{*}{ Показник } & \multicolumn{2}{|c|}{ До крос-лінкінгу } & \multicolumn{2}{c|}{1 міс, } & \multicolumn{2}{c|}{3 міс, } & \multicolumn{2}{c|}{6 міс, } \\
\cline { 2 - 10 } & основна & контроль & основна & контроль & основна & контроль & основна & контроль \\
\hline vis б/к & $0,18 \pm 0,04$ & $0,46 \pm 0,01^{* *}$ & $0,22 \pm 0,04$ & $0,44 \pm 0,01^{* *}$ & $0,24 \pm 0,04$ & $0,44 \pm 0,01^{* *}$ & $0,25 \pm 0,04$ & $0,43 \pm 0,01^{* *}$ \\
\hline vis з КК & $0,91 \pm 0,03$ & $0,95 \pm 0,01$ & $0,93 \pm 0,03$ & $0,95 \pm 0,01$ & $0,94 \pm 0,03$ & $0,94 \pm 0,01$ & $0,94 \pm 0,03$ & $0,94 \pm 0,01$ \\
\hline $\begin{array}{l}\text { Найтонша } \\
\text { точка,мм }\end{array}$ & $0,41 \pm 0,01$ & $0,47 \pm 0,01^{* *}$ & $0,42 \pm 0,01$ & $0,47 \pm 0,01^{* *}$ & $0,43 \pm 0,01$ & $0,46 \pm 0,01^{* *}$ & $0,44 \pm 0,01 *$ & $0,45 \pm 0,01$ \\
\hline Kmax, D & $51,71 \pm 1,43$ & $47,83 \pm 1,24$ & $51,65 \pm 1,43$ & $47,97 \pm 1,25$ & $51,47 \pm 1,40$ & $48,01 \pm 1,27$ & $51,17 \pm 1,45$ & $48,03 \pm 1,29$ \\
\hline K min, D & $47,98 \pm 1,39$ & $45,85 \pm 0,94$ & $47,93 \pm 1,40$ & $45,85 \pm 0,94$ & $47,85 \pm 1,39$ & $45,87 \pm 0,96$ & $47,80 \pm 1,39$ & $45,89 \pm 0,96$ \\
\hline Kcyl, D & $3,73 \pm 0,53$ & $1,97 \pm 0,72$ & $3,72 \pm 0,52$ & $2,10 \pm 0,73$ & $3,67 \pm 0,54$ & $2,15 \pm 0,76$ & $3,31 \pm 0,50$ & $2,17 \pm 0,77$ \\
\hline \hline
\end{tabular}

Примітки:

1) різниця статистично значима (p<0,05) * - між однаковими показниками у межах однієї групи в часі (через 6 місяців);

$2)^{* *}$ - між основною і контрольною групами в межах одного показника. 
3. На парних очах із початковим кератоконусом, де УФ-Х терапія не проводилась, рогівка продовжує витончуватись та стає крутішою, що погіршує гостроту зору та свідчить про прогресування захворювання.

\section{СПИСОК ЛІТЕРАТУРИ}

1. Аверьянова О. С. Настоящее и будущее кросс-линкинга / О. С. Аверьянова // Мир офтальмологии. - 2010. - № 1. C. 16-17.

2. Фототерапія захворювань рогівки ока / Салдан Й. Р., Луцюк М. Б., Салдан Ю. Й. [та ін.] // Фотобиология и фотомедицина. - 2009. - № 3. - С. 107-111.

3. CaporossiA. Parasurgical therapy for keratoconus by riboflavinultraviolet type A rays induced cross-linking of corneal collagen: preliminary refractive results in an Italian study / A. Caporossi. S. Baiocchi, C. Mazzotta // J. Cataract. Refract. Surg. - 2006. Vol. 32(5). - P. 837-845.

4. Long-term results of riboflavin ultraviolet a corneal collagen
Перспективи подальших досліджень. Для кращого розуміння феномена необхідні подальше спостереження і більша кількість досліджень.

cross-linking for keratoconus in Italy: the Siena eye cross study / A. Caporossi, C. Mazzotta, S. Baiocchi, T. Caporossi // J. Cataract. Refract. Surg. - 2010. - Vol. 149(4). - P. 585-593.

5. Gomez-Miralles1 M. Biomechanical corneal response measurement aftermanual insertion of intrastromal rings in patients with keratoconus / M. Gomez-Miralles1, C. Peris-Martinez1, F. Pastor-Pascual1 // J. of Emmetropia. - 2010. - Vol.1 - - P. 207212.

6. Panico C. Transepthelial corneal cross-linking: evaluation of treatment efficacy in relation to the initial evolutionary stage / C. Panico, R. Protti, E. Savio // Abstracts of $2^{\text {nd }}$ International Congress Refractive.online \& SICSSO. - Rome, 2012.

Отримано 25.01.13 